\title{
Immune cells and cytokine production in the bovine corpus luteum throughout the oestrous cycle and after induced luteolysis
}

\author{
L. A. Penny ${ }^{1}$, D. Armstrong ${ }^{2}$, T. A. Bramley ${ }^{3}$, R. Webb ${ }^{4}$, R. A. Collins ${ }^{5}$ and E. D. Watson ${ }^{1}$ \\ ${ }^{2}$ Department of Veterinary Clinical Studies, Royal (Dick) School of Veterinary Studies, University of Edinburgh EH25 9RG, UK; \\ ${ }^{2}$ Division of Development and Reproduction, Roslin Institute (Edinburgh), Roslin, Midlothian EH25 9PS, UK; ${ }^{3}$ Department of Obstetrics \\ and Gynaecology, University of Edinburgh, Centre of Reproductive Biology, 37 Chalmers Street, Edinburgh EH3 9EW, UK; \\ ${ }^{4}$ Department of Agriculture and Horticulture, University of Nottingham, Leicestershire LE12 5RD, UK; and \\ ${ }^{5}$ Institute for Animal Health, Compton, Berkshire RG20 7NN, UK
}

\begin{abstract}
Immune cells and their cytokine products have powerful local effects within body tissues. There has been great interest in the potential role of these cells, not only during destruction of the corpus luteum but also during its functional lifespan. In this study, lymphocytes, macrophages and major histocompatibility complex class II molecules were quantified using immunohistochemistry and the reverse transcriptionpolymerase chain reaction was used to detect mRNA for tumour necrosis factor $\alpha$ and interferon $\gamma$ within corpora lutea from three groups of cows: (1) corpora lutea collected at an abattoir and assessed visually into four stages (stage I (days 1-5), stage II (days 6-12), stage III (days 13-18) and stage IV (days 19-21) of the oestrous cycle); (2) corpora lutea collected around natural luteolysis (days 14-20); and (3) corpora lutea collected 6, 12 and $24 \mathrm{~h}$ after prostaglandin $\mathrm{F}_{2 \alpha}$-induced luteolysis. The numbers of $\mathrm{T}$ lymphocytes $\left(\mathrm{CD}^{+}\right.$ and $\left.\mathrm{CD}^{+}\right)$were significantly higher $(P<0.05)$ at stage IV and from day 16 onwards, before functional luteolysis. There were significantly higher numbers $(P<0.01)$ of macrophages at stages I, III and IV compared with stage II in visually staged tissue. Major histocompatibility complex class II molecules were increased $(P<0.05)$ at stages I and IV compared to stage II and at all times after induced luteolysis. Using reverse transcription- polymerase chain reaction, mRNA encoding tumour necrosis factor $\alpha$ and interferon $\gamma$ was detected in all luteal tissue collected around natural luteolysis and after induced luteolysis. These findings, particularly the increase in $\mathrm{T}$ lymphocytes before functional luteolysis, provide further evidence of a significant role for the immune system in affecting reproductive function in cows.
\end{abstract}

\section{Introduction}

The bovine corpus luteum, in common with that of other species, is composed of a variety of cell types. Large and small luteal cells are present in various proportions at different stages of the oestrous cycle and there are also significant numbers of non-luteal cells, such as epithelial cells, fibroblasts and immune cells, within bovine luteal tissue (Alila and Hansel, 1984; O'Shea et al., 1989; Lei et al., 1991). In non-pregnant cows, the corpus luteum undergoes luteolysis and becomes non-functional around days 17-18 after ovulation in response to prostaglandin $\mathrm{F}_{2 \alpha}\left(\mathrm{PGF}_{2 \alpha}\right)$ released from the uterus (Niswender $e t$ al., 1985). Circulating progesterone concentrations fall sharply (functional luteolysis), resulting in the physical breakdown of the corpus luteum (structural luteolysis).

Immune cell populations have been observed within corpora lutea from a range of species including guinea-pigs

Received 16 March 1998.
(Paavola, 1979), rabbits (Bagavandoss et al., 1988), pigs (Standaert et al., 1991), mares (Lawler et al., 1994), humans (Wang et al., 1992; Brannstrom et al., 1994, Best et al., 1996) and cattle (Lobel and Levey, 1968; Spanel-Borowski et al., 1997). Some studies have demonstrated variations in immune cells present in the ovary at different stages of the oestrous cycle, although there are some differences among species (Standaert et al., 1991; Brannstrom et al., 1994). Niswender et al. (1976) suggested that these immune cells are present primarily as a result of the high blood flow to the corpus luteum and that they play a passive role for most of the oestrous cycle until the time of luteolysis. The main function of the immune cells at luteolysis is thought to be destruction of the luteal tissue through a variety of processes, including phagocytosis (Paavola, 1979). However, increasing integration of both immunological and endocrinological aspects of luteal function (for review, see Mori, 1990; Adashi, 1992) suggests that immune cells may have an active role in controlling the lifespan and function of the corpus luteum.

Major histocompatibility complex (MHC) molecules are 
cell surface markers required for the recognition of antigen by $\mathrm{T}$ lymphocytes during an immune response. MHC class I molecules are found on all nucleated cells, whereas expression of MHC class II antigens is more limited and is associated with cells, such as macrophages, that function as antigen-presenting cells. MHC class II molecules may also occur in cells outside the immune system (Roitt, 1991), including luteal cells. MHC class II molecules within the corpus luteum are of interest since they would be central to any T-lymphocyte-mediated immune response in luteal tissue, particularly during luteolysis. Fairchild et al. (1991) showed that expression of MHC class II molecules on bovine luteal cells increased with age of corpus luteum and hypothesized that they are involved in controlling the lifespan of the cow corpus luteum.

Immune cells can exert their effects through the production of cytokines, soluble protein molecules that act as intercellular messengers. Cytokine production within corpora lutea from a range of species has been described, although results vary considerably (Vinatier et al., 1995). There has been particular interest in tumour necrosis factor $\alpha$ (TNF- $\alpha$ ) because its cytotoxic action on tumour cells has been compared with luteal regression (Ji et al., 1991). For this reason, TNF- $\alpha$ has been investigated in most detail within the corpus luteum (Terranova et al., 1993; Hunt, 1993). TNF- $\alpha$ has been detected in cow corpus luteum by immunohistochemistry (Roby and Terranova, 1989) and radioimmunoassay of dialysate collected from the corpus luteum around luteolysis (Shaw and Britt, 1995). In addition, a considerable number of in vitro studies have been published relating to the effects of TNF- $\alpha$, interferon $\gamma$ (IFN- $\gamma$ ), and interleukin-1 $\beta$ (IL-1 $\beta$ ), either individually or in combination, on bovine luteal cells in culture (for review, see Pate, 1995).

If immune cells and their cytokine products do have a primary role in controlling the corpus luteum, it is likely that populations of immune cells or cytokine production within the corpus luteum will change during the oestrous cycle, particularly around key events, such as ovulation and luteolysis. The aim of the present study was to investigate whether there are changes in immune cell populations, expression of MHC class II molecules and cytokine production in the bovine corpus luteum during the oestrous cycle, particularly around the time of natural luteolysis and after induced luteolysis.

\section{Materials and Methods}

\section{Animals}

Experiment 1: oestrous cycle. Ovaries were collected from continental-cross heifers within $30 \mathrm{~min}$ of slaughter at a local abattoir and corpora lutea were staged visually $(n=6$ per stage) as described by Ireland et al. (1980): stage I, days 1-5; stage II, days 6-12; stage III, days 13-18; and stage IV, days 19-21. When this method is used, day 0 is the day of oestrus.

Experiment 2: natural luteolysis. The oestrous cycles of 27 mature Friesian-cross heifers were synchronized using progesterone-impregnated intravaginal devices (PRID;
Sanofi Animal Health, Watford) for 12 days. Cloprostenol $(500 \mu \mathrm{g})$, a synthetic PGF $_{2 \alpha}$ analogue (Estrumate; Schering Plough Animal Health, Uxbridge) was given by i.m. injection on day 10. After PRID removal, the animals were observed for signs of oestrus three times per day and jugular blood samples were taken to confirm oestrus at this time. Ovaries were then collected at slaughter between day 13 and day 20 of the oestrous cycle. Daily blood samples were taken for 2-3 days before and at slaughter for progesterone analysis to assess whether functional luteolysis had taken place.

Experiment 3: induced luteolysis. The oestrous cycles of 16 Friesian or Ayrshire cows were synchronized as described for Expt 2. On day 10 after oestrus, the ovary bearing the corpus luteum was identified by ultrasound examination. Animals were assigned to one of four groups and luteolysis was induced in three of the groups using an i.m. injection of $25 \mathrm{mg}$ dinoprost, a synthetic form of natural PGF ${ }_{2 \alpha}$ (Lutalyse; Upjohn Ltd, Crawley) 6, 12 or $24 \mathrm{~h}$ before removal of the corpus luteum. The fourth group of control animals did not receive any $\mathrm{PGF}_{2 \alpha}$. At the time of surgery, each animal was sedated using $0.05-0.1 \mathrm{mg}$ xylazine $\mathrm{kg}^{-1}$ (Rompun, Bayer plc, Bury St Edmunds) and local anaesthesia of the surgical site was achieved by infiltration with $2 \%(\mathrm{w} / \mathrm{v})$ lignocaine (Lignavet; C-Vet, Leyland). A $10 \mathrm{~cm}$ incision was made through the body wall and the corpus luteum was removed from the ovary by enucleation. The wound was closed in three layers and cows were given prophylactic antibiotic cover at this time. Blood samples for progesterone analysis were taken from the jugular vein immediately before $\mathrm{PGF}_{2 \alpha}$ injection and at surgery.

\section{Blood sampling and tissue collection}

Blood samples $(7 \mathrm{ml})$ were collected into tubes containing $143 \mathrm{U}$ heparin (Vacutainer; Becton Dickinson UK Ltd, Cowley) and centrifuged at $1000 \mathrm{~g}$ for $30 \mathrm{~min}$. The plasma was then stored at $-20^{\circ} \mathrm{C}$ until progesterone assay.

Corpora lutea were dissected free from the surrounding ovarian tissue, weighed and cut into four pieces. Luteal tissue to be used for immunohistochemistry was placed in OCT compound (Miles Inc., Elkhart, IN), snap-frozen in a mixture of dry ice and isopentane and stored at $-70^{\circ} \mathrm{C}$. A separate piece of corpus luteum was also fixed for $24 \mathrm{~h}$ in $10 \%(\mathrm{v} / \mathrm{v})$ buffered neutral formalin and then processed for histological examination (haematoxylin and eosin staining and carbol chromotrope staining to detect eosinophils). In addition, portions of luteal tissue collected from animals in Expts 2 and 3 were snap-frozen in foil for use in molecular studies. Corpora lutea from cows in Expt 1 were not used for molecular work because of the difficulty in minimizing RNase contamination during collection.

\section{Progesterone assay}

Plasma progesterone concentrations were measured using a radioimmunoassay described by Corrie et al. (1981) and modified by Law et al. (1992). All samples were measured in 
a single assay with an intra-assay coefficient of variation (CV) of $13.9 \%$.

\section{Immunohistochemistry}

Sections of frozen luteal tissue $(6 \mu \mathrm{m})$ were cut on a cryostat, mounted onto gelatin-coated slides (Biobond; British Biocell International, Cardiff, UK) and air-dried for $2 \mathrm{~h}$. The sections were then fixed in cold acetone for $5 \mathrm{~min}$ and washed in PBS $\left(0.1 \mathrm{moll}^{-1}, \mathrm{pH} 7.3\right)$, before staining by a modified avidin-biotin complex $(\mathrm{ABC})$ method described by Hsu et al. (1981) using a Vectastain Elite ABC Kit (Vector Laboratories, Bretton, Peterborough). Cell types identified by immunohistochemistry were $\mathrm{T}$ lymphocytes, macrophages and MHC class II molecules. The T-lymphocyte subsets identified were $\mathrm{CD}^{+}$(all mature $\mathrm{T}$ lymphocytes plus a subset of B lymphocytes), $\mathrm{CD}^{+}$(cytotoxic-suppressor $\mathrm{T}$ lymphocytes) and $\mathrm{CD}^{+}$(helper- inducer $\mathrm{T}$ lymphocytes). The primary antibodies used are shown (Table 1).

Endogenous peroxidase staining was blocked by treating the sections with $5 \mathrm{U}$ glucose oxidase $\mathrm{ml}^{-1}$ in $10 \mathrm{mmol} \beta$-Dglucose, $1 \mathrm{mmol}$ sodium azide $\mathrm{l}^{-1}$ and PBS $\left(0.1 \mathrm{~mol} \mathrm{l}^{-1}, \mathrm{pH}\right.$ 7.3) for $50 \mathrm{~min}$ at $37^{\circ} \mathrm{C}$. Sections were then treated with $1.5 \%$ normal horse serum for $15 \mathrm{~min}$ at room temperature, primary antibody was added and the sections were incubated overnight at $4^{\circ} \mathrm{C}$. Biotinylated secondary antibody was added, and then the avidin-biotin reagent (both for 30 min at room temperature). The slides were washed between reagents for $10 \mathrm{~min}$ with $\mathrm{PBS}$. A red reaction product was obtained by incubating with 3-amino-9-ethyl carbazole (AEC) for 10-15 min. The slides were then washed in tap water, counterstained in Meyer's haematoxylin and mounted using Immu-mount, an aqueous mounting solution (Shandon; Pittsburgh, PA).

In each batch of stained slides, one slide was included in which normal mouse serum was substituted for primary antibody (negative control) and sections of bovine lymph node were processed throughout (positive control).

Eosinophils were detected on formalin-fixed sections cut from paraffin wax-embedded tissue using the carbol chromotrope method described by Lendrum (1944). Sections of gut were used as positive controls. Tissue sections embedded in paraffin wax were also stained with haematoxylin and eosin for general assessment of the morphology of each corpus luteum.

\section{Reverse transcription-polymerase chain reaction}

RNA for RT-PCR was isolated from corpora lutea using the guanidium thiocyanate method (Chomczynski and Sacchi, 1987). Concentrations were estimated by absorbance at $260 \mathrm{~nm}$ and the samples were stored in diethylpyrocarbonate (DEPC)-treated $\mathrm{H}_{2} \mathrm{O}$ until required. The $\mathrm{A}_{260}: \mathrm{A}_{280}$ ratio for all samples was $>1.6$. In addition, samples were checked for evidence of RNA degradation by formaldehyde gel electrophoresis looking for two distinct bands corresponding to $28 \mathrm{~S}$ and $18 \mathrm{~S}$ ribosomal RNA. First strand CDNA synthesis was carried out using a modification of the method described by Armstrong et al. (1992). Briefly, total RNA $(1 \mu \mathrm{g})$ was reverse transcribed in RTase buffer ( 250 mmol Tris- $\mathrm{HCl} \mathrm{l}^{-1}$, $\mathrm{pH} 8.3 ; 375 \mathrm{mmol} \mathrm{KCl} \mathrm{^{-1 }} ; 15 \mathrm{mmol} \mathrm{MgCl}$, $1^{-1}$; Gibco BRL, Life Technologies, Paisley), dNTP mix (0.5 $\mu \mathrm{mol} \mathrm{l}^{-1}$; Pharmacia Biotech, St Albans), RNasin (4 U, Promega UK Ltd, Southampton) and Superscript ${ }^{\mathrm{TM}}$ II reverse transcriptase (13.5 U, Gibco BRL) at $37^{\circ} \mathrm{C}$ for $60 \mathrm{~min}$. The reverse transcriptase reaction medium was diluted to $100 \mu \mathrm{l}$ after the addition of $8 \mu \mathrm{l}$ of $10 \times \mathrm{PCR}$ buffer and stored at $-20^{\circ} \mathrm{C}$.

Primer sequences and cytokine plasmid for TNF- $\alpha$ and IFN- $\gamma$ were provided by R. Collins (Institute for Animal Health, Compton). Primer sequences and PCR product sizes are shown (Table 2). The PCR conditions (the amount of cDNA, annealing temperature and number of amplification cycles) were optimized for both cytokines.

The PCR reaction was carried out using $10 \mu \mathrm{l}$ of the diluted reverse transcription reaction (equivalent to $0.1 \mu \mathrm{g}$ of the original total RNA), $1 \mu \mathrm{l}$ of $10 \times$ PCR buffer, $100-200$ pmol each of $5^{\prime}$ and $3^{\prime}$ primers and $1 \mathrm{U}$ Taq DNA polymerase (Gibco BRL) in a total volume of $20 \mu \mathrm{l}$. The samples were heated to $94^{\circ} \mathrm{C}$ for $5 \mathrm{~min}$ and amplified for 30 cycles for TNF$\alpha$ and 35 cycles for IFN- $\gamma\left(93^{\circ} \mathrm{C}\right.$ for $30 \mathrm{~s} ; 60^{\circ} \mathrm{C}$ for $30 \mathrm{~s} ; 72^{\circ} \mathrm{C}$ for $30 \mathrm{~s}$ ) using a Biometra Personal Cycler (Biometra, Maidstone). The final $72^{\circ} \mathrm{C}$ incubation was continued for a further 5 min. RT blanks (no RNA) and PCR blanks (no

Table 1. Monoclonal antibodies (mAb) used in the course of the study

\begin{tabular}{|c|c|c|c|c|c|}
\hline $\mathrm{mAb}$ & Specificity & Isotype & Source & Form & Dilution \\
\hline $\mathrm{CC} 17^{\mathrm{a}}$ & CD5 & IgG1 & IAH, Compton & $\mathrm{S}$ & $1 / 10$ \\
\hline СACT $80-C$ & $\begin{array}{l}\text { CD8 } \\
\text { T-suppressor/cytotoxic }\end{array}$ & $\operatorname{IgG1}$ & VMRD, Pullman, WA & $\mathrm{AF}$ & $1 / 200$ \\
\hline $\mathrm{CC}^{\mathrm{b}}$ & $\begin{array}{l}\mathrm{CD} 4 \\
\text { T-helper/inducer }\end{array}$ & $\operatorname{lgG} 2 a$ & IAH, Compton & $s$ & $1 / 5$ \\
\hline DU2104 & B-cell & $\operatorname{IgM}$ & Basel Institute & $\mathrm{s}$ & $1 / 5$ \\
\hline DH59B & GM1 & $\operatorname{IgG1}$ & VMRD, Pullman, WA & $\mathrm{AF}$ & $1 / 2000$ \\
\hline TH14B & MHCII (DR) & $\operatorname{IgG} 2 a$ & VMRD, Pullman, WA & $\mathrm{AF}$ & $1 / 1500$ \\
\hline VPM36 & MHCII (DQ) & IgG1 & $\begin{array}{l}\text { Dept Veterinary Pathology, } \\
\text { University of Edinburgh }\end{array}$ & $\mathrm{s}$ & $1 / 20$ \\
\hline
\end{tabular}

${ }^{\mathrm{a}}$ Howard et al., 1988; ${ }^{\mathrm{b}}$ Howard and Morrison, 1991.

$\mathrm{S}$, supernatant; $\mathrm{AF}$, ascites fluid. 
Table 2. Primer sequences and PCR product sizes for tumour necrosis factor $\alpha$ (TNF- $\alpha$ ), interferon $\gamma$ (IFN- $\gamma$ ) and ATPase

\begin{tabular}{llc}
\hline Cytokine & \multicolumn{1}{c}{ Primer sequences } & PCR product size (number of base pairs) \\
TNF- $\alpha$ & 5'-ACTCAGGTCATCTTCTCAAGCC-3' & 464 \\
& 5'-ATGATCCCAAAGTAGACCTGCC-3' & \\
IFN- $\gamma$ & 5'-GCAAGTAGCCCAGATGTAGC-3' & 316 \\
& 5'-GGTGACAGGTCATTCATCAC-3' & \\
ATPase & 5'-ACGAACACCACTCCTGGATGAGC-3' & \\
& 5'-CACGGACGTCTCCAGGCTGTGTA-3' \\
\hline
\end{tabular}

cDNA products) were included in each analysis. RT-PCR for ATPase was used as an interassay control. The ATPase primers are shown (Table 2). In addition, the plasmids for both cytokines were amplified as a positive control. The products were visualized by electrophoresis on $4 \%(\mathrm{w} / \mathrm{v})$ agarose gels (NuSieve GTG Agarose; FMC Bioproducts, Rockland, ME). In all experiments, reverse transcriptase and PCR blanks were negative. The identities of the different PCR products were confirmed by restriction endonuclease digestion. Under the conditions described, the amount of PCR product produced using the different primers was proportional to the number of thermo-cycles of the PCR reaction and the mass of RNA added to the reverse transcriptase reaction.

\section{Statistical analysis}

The immunohistochemistry results were analysed using the Kruskal-Wallis test for non-parametric data. The Mann-Whitney $U$ test was then used to analyse differences between samples. A $P$ value $<0.05$ was taken to be significant. Progesterone concentrations (Expt 3) before and after treatment with PGF $_{2 \alpha}$ were compared using a paired Student's $t$ test. A $P$ value $<0.05$ was taken to be significant. All statistical analyses were performed using Minitab software (Pennsylvania State University).

\section{Results}

\section{Immunohistochemistry}

Cell counts. Before counting the positively stained cells, the general distribution of immune cell populations within the luteal tissue was assessed. Individual lymphocytes and monocytes-macrophages were found scattered among the luteal cells (Fig. 1a,b) and there were also occasional clumps of lymphocytes that tended to be associated with larger blood vessels. Lymphocytes and macrophages were found in greater numbers in the capsule of the corpus luteum and in trabeculae extending from the capsule. MHC class II molecules, identifying both the HLA-DQ and HLA-DR region of the gene (Dutia et al., 1995), were the most difficult to evaluate because staining was less clearly associated with individual cells (Fig. 1c).
After this preliminary assessment, it was decided to look at regions of the corpus luteum that were seen to be made up primarily of luteal cells when counting stained cells in experimental tissue. Therefore, the capsule and associated fibrous areas were avoided, as were fields dominated by large blood vessels. A mean figure was calculated for each animal after counting six fields per luteal section as described above. These figures were then used to calculate the mean and standard error of the mean within each group ( $n=4-7$ animals). When assessing MHC class II molecules, only cells with a clear positive stain were included.

\section{Experiment 1: oestrous cycle}

Immunohistochemistry/tissue morphology. The numbers of $\mathrm{CD}^{+}$and $\mathrm{CD} 8^{+}$lymphocytes were not significantly different among stages I, II and III (Table 3 ). However, there were significantly more $(P<0.01) \mathrm{CD}^{+}$and $\mathrm{CD} 8^{+}$cells in stage IV compared with stage II corpus luteum. The number of $\mathrm{CD}^{+}$ cells did not vary at any stage (Table 3 ). The number of $B$ lymphocytes was very low in all sections of luteal tissue with, at most, two or three cells in total per six fields.

There were significantly $(P<0.01)$ more macrophages present in stage I, III and IV compared with stage II corpus luteum, with the highest numbers recorded at stages I and IV (Table 3 ). The number of MHC class II molecules (DR) was significantly $(P<0.01)$ higher in samples of stage IV corpus luteum when compared with stages I-III (Table 3). The number of MHC class II molecules (DQ) was significantly higher in both stage I $(P<0.05)$ and stage IV $(P<0.01)$ corpus luteum compared with stages II and III corpus luteum (Table 3). Eosinophils were present in substantially higher numbers in stage I corpus luteum $(P<0.01)$ than in corpus luteum at any other stage (Table 3 ). There was a marked difference in the number of cells present in stage I (10-75 cells per field) compared with that of stages II-IV corpus luteum ( $0-3$ cells per field).

Sections stained with haematoxylin and eosin were examined. In stage I luteal tissue, eosinophils were the most striking feature with little distinct luteal structure developed and the remnants of the ruptured follicle clearly visible. Stage II and III luteal tissue was similar morphologically, with distinct large luteal cells interspersed with small luteal cells, fibroblasts and small round darkly staining cells assumed to be lymphocytes. Stage IV luteal tissue had a far 
Table 3. Positively stained immune cells and major histocompatibility complex (MHC) class II expression (mean \pm SEM) in visually staged bovine luteal tissue from four stages of the oestrous cycle

\begin{tabular}{lcccc}
\hline & \multicolumn{4}{c}{ Stage of cycle } \\
\cline { 2 - 5 } Cell type & I & II & III & IV \\
\hline CD5 $^{+}$ & $23.75 \pm 4.2$ & $22.47 \pm 5.0$ & $25.11 \pm 3.2$ & $62.61 \pm 6.1^{* *}$ \\
$\mathrm{CD}^{+}$ & $12.03 \pm 1.8$ & $12.06 \pm 2.6$ & $13.05 \pm 2.8$ & $46.41 \pm 6.5^{* *}$ \\
$\mathrm{CD}^{+}$ & $5.08 \pm 1.0$ & $3.58 \pm 0.9$ & $6.08 \pm 1.3$ & $1.83 \pm 0.5$ \\
Macrophages-monocytes & $23.61 \pm 4.6^{* *}$ & $5.05 \pm 0.5$ & $13.89 \pm 2.4^{* *}$ & $23.75 \pm 4.9^{* *}$ \\
MHC II (DQ) & $17.02 \pm 1.8^{*}$ & $12.75 \pm 0.8$ & $10.16 \pm 0.8$ & $24.72 \pm 2.7^{* *}$ \\
MHC II+ (DR) & $14.14 \pm 2.6$ & $10.39 \pm 1.4$ & $11.17 \pm 1.7$ & $23.78 \pm 3.9^{* *}$ \\
Eosinophils & $17.17 \pm 2.3^{* *}$ & $0.61 \pm 0.2$ & $1.08 \pm 0.4$ & $0.28 \pm 0.1$ \\
\hline
\end{tabular}

aStage I, days 1-5; stage II, days 6-12; stage III, days 13-18; stage IV, days 19-21.

A mean figure was calculated for each animal after counting six fields per luteal section. These figures were then used to calculate the mean \pm SEM for each group as shown in the table. Each figure represents mean \pm SEM results from six corpora lutea.

$* P<0.05$ compared with stage II; ${ }^{* *} P<0.01$ compared with stage II.

Table 4. Immune cell populations and major histocompatibility complex (MHC) class II expression (mean \pm SEM) in bovine corpora lutea collected around the time of natural luteolysis

\begin{tabular}{lcccc}
\hline Cell type & $\begin{array}{c}\text { Group A } \\
\text { (days 13-14) }\end{array}$ & $\begin{array}{c}\text { Group B } \\
\text { (days 16-17) }\end{array}$ & $\begin{array}{c}\text { Group C1 } \\
\text { (days 18-20; } \\
\text { high progesterone) }\end{array}$ & $\begin{array}{c}\text { Group C2 } \\
\text { (days 18-20; } \\
\text { low progesterone) }\end{array}$ \\
\hline Macrophages & $9.74 \pm 2.7$ & $7.81 \pm 1.1$ & $5.09 \pm 1.0$ & $10.70 \pm 3.9$ \\
MHC II ${ }^{+}$(DQ) & $10.33 \pm 1.7$ & $10.06 \pm 1.4$ & $8.57 \pm 0.5$ & $10.03 \pm 1.7$ \\
MHC II (DR) & $7.48 \pm 0.7$ & $12.11 \pm 3.1$ & $9.09 \pm 1.4$ & $10.63 \pm 1.4$ \\
Eosinophils & $0.38 \pm 0.2$ & $0.94 \pm 0.2$ & $0.64 \pm 0.2$ & $5.03 \pm 2.9$ \\
B cells & 0 & 0.28 & 0.02 & 0 \\
\hline
\end{tabular}

Each figure represents mean results from a minimum of five animals.

more fibrous appearance. There were areas where luteal cells could be identified but these cells were often shrunken, vacuolated and had lost their shape. In some areas, no clear luteal cells could be seen. The staining was much more intense and blood vessels were difficult to identify.

\section{Experiment 2: natural luteolysis}

Variation in time of slaughter resulted in three groups of corpora lutea from between day 13 and day 20 of the oestrous cycle. Group A animals $(n=7)$ were slaughtered on days 13-14; group $B$ animals $(n=6)$ on days 16-17; and group $C$ animals $(n=12)$ on days 18-20. Two animals were excluded from the study, one animal had a luteal cyst and the other was not observed to be in oestrus at any time after synchronization.

Progesterone. Progesterone concentrations were used to monitor whether corpora lutea had undergone functional luteolysis in the days leading up to slaughter. As the decrease in progesterone concentrations occurs before structural regression, this is the most useful indicator of alterations in luteal function. Luteolysis was considered to have occurred when the concentration of plasma progesterone was $<1 \mathrm{ng} \mathrm{ml}^{-1}$.

Group A, group B and seven animals from group C had progesterone concentrations consistent with a functional corpus luteum for the 3 days before and at the time of slaughter (progesterone $>1 \mathrm{ng} \mathrm{ml}^{-1}$, range $1.5-6.9 \mathrm{ng} \mathrm{ml}^{-1}$ ). Five animals in group $\mathrm{C}$ had undergone functional luteolysis, as indicated by progesterone concentrations of $<1 \mathrm{ng} \mathrm{ml}^{-1}$ at time of slaughter (range $0.2-0.9 \mathrm{ng} \mathrm{ml}^{-1}$ ). On this basis, group $\mathrm{C}$ was divided into a high progesterone group (C1) and a low progesterone group $(\mathrm{C} 2)$.

Immunohistochemistry-tissue morphology. The four groups of animals (A, B, C1 and C2) were compared. Animals from groups $\mathrm{B}, \mathrm{C} 1$ and $\mathrm{C} 2$, (that is, all corpora lutea from day 16 onwards) had significantly greater $(P<0.05)$ numbers of both $\mathrm{CD}^{+}$and $\mathrm{CD} 8^{+}$lymphocytes in comparison with animals from group A (Fig. 2). There was no significant difference in the number of $\mathrm{T}$ lymphocytes between groups $\mathrm{C} 1$ and $\mathrm{C} 2$. There were no significant differences in the numbers of $\mathrm{CD}^{+}$cells (Fig. 2), macrophages, eosinophils or MHC class II molecules (DQ or DR) among groups (Table 4). B lymphocytes were present in insignificant numbers in all samples.

It was possible to see the increase in lymphocytes from day 16 onwards when sections stained with haematoxylin and eosin were examined, particularly where the cells in these sections were in clumps around blood vessels. Before completion of the progesterone assay, all sections were examined in an attempt to predict the animals that had undergone luteolysis during the course of the experiment. Convincing signs of structural luteolysis (loss of tissue structure, shrinkage of luteal cells and a generally more 

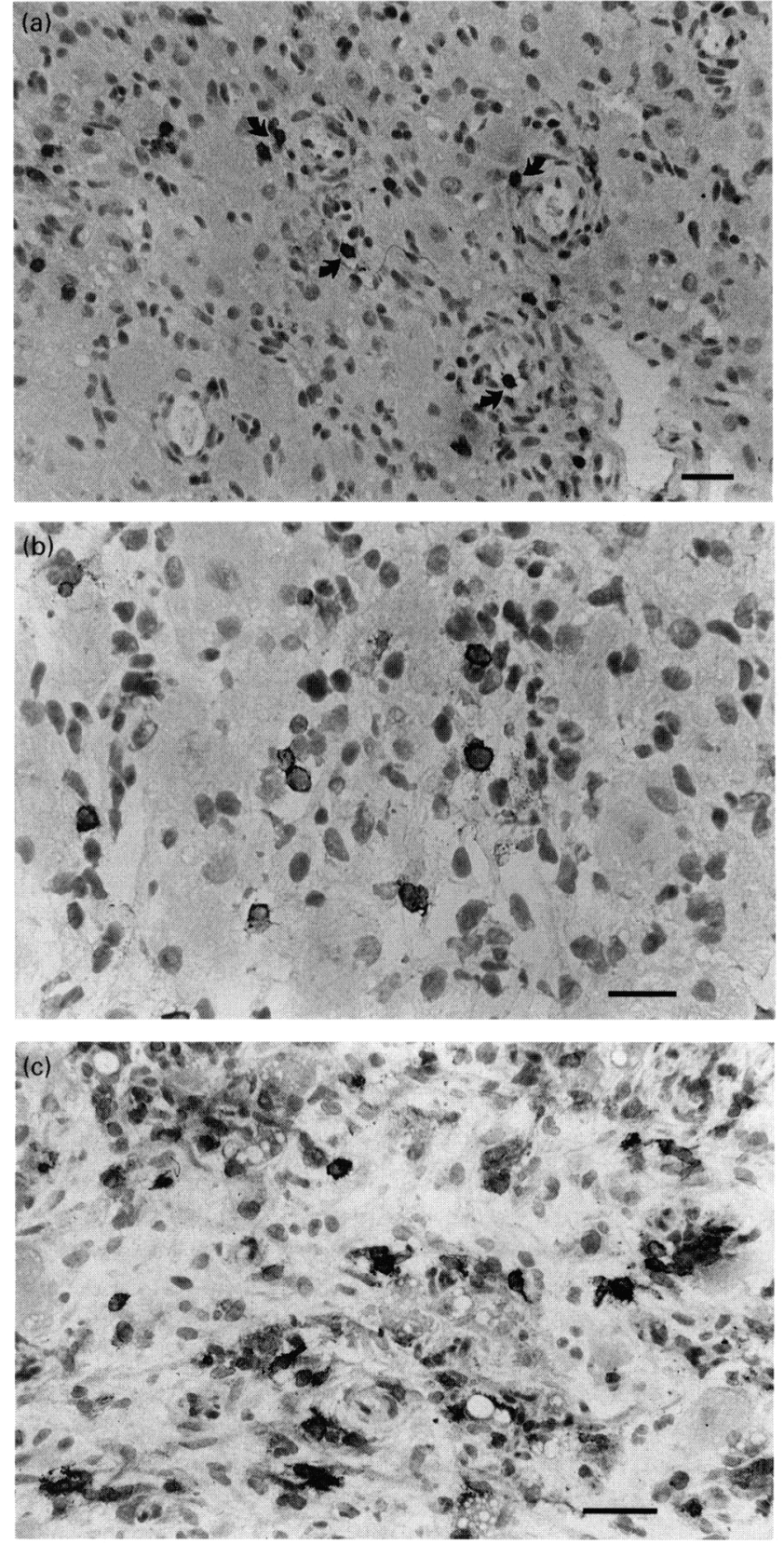

Fig. 1. The appearance of different cell types within bovine luteal tissue sections: (a) $\mathrm{CD}^{+} \mathrm{T}$ lymphocytes (arrows); (b) macrophages; and (c) MHC II expression. Scale bars represent (a) $50 \mu \mathrm{m},(\mathrm{b}, \mathrm{c}) 30 \mu \mathrm{m}$.

fibrous appearance) were seen in a section of luteal tissue from only one animal.

\section{Experiment 3: induced luteolysis}

Progesterone. Control animals had progesterone concentrations consistent with a functional corpus luteum $\left(1.87 \pm 0.4 \mathrm{ng} \mathrm{ml}^{-1}\right)$ on the day of surgery. At the time of $\mathrm{PGF}_{2 x}$ injection, the three treatment groups $(6,12$ and $24 \mathrm{~h})$ had plasma progesterone concentrations (mean \pm SEM, $n=4$

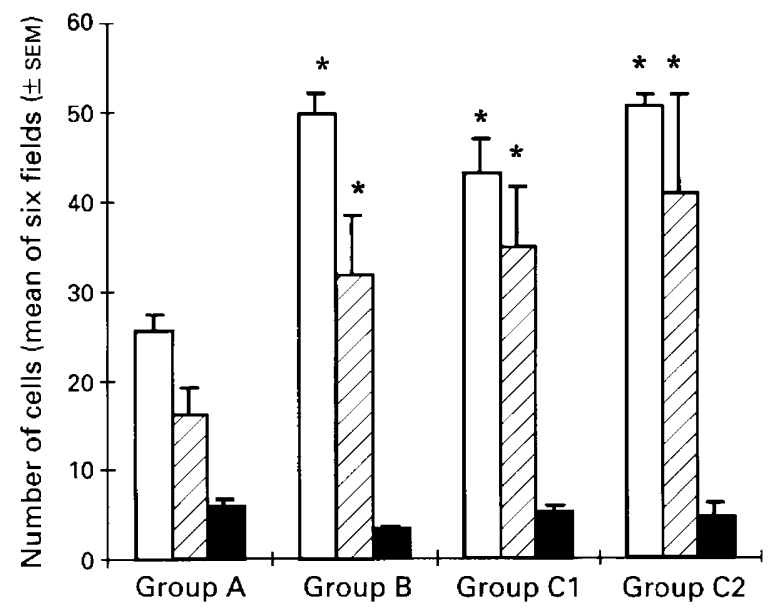

Fig. 2. T-lymphocyte populations $(\square, C D 5 ; \square, C D 8 ; \square, C D 4)$ within bovine luteal tissue at days 13-14 (group A), days 16-17 (group B), days 18-20, high progesterone (group $\mathrm{C} 1$ ) and days 18-20, low progesterone (group C2). *Significantly different $(P<0.05)$.

per group) of $5.2 \pm 1.0 \mathrm{ng} \mathrm{ml}^{-1}, 1.87 \pm 0.5 \mathrm{ng} \mathrm{ml}^{-1}$ and $3.68 \pm$ $0.4 \mathrm{ng} \mathrm{ml}^{-1}$, respectively. At the time of surgery, progesterone concentrations were $2.6 \pm 0.6 \mathrm{ng} \mathrm{ml}^{-1}, 1.4 \pm 0.4 \mathrm{ng} \mathrm{ml}^{-1}$ and $0.92 \pm 0.1 \mathrm{ng} \mathrm{ml}^{-1}$, respectively. The decrease in progesterone concentration after $\mathrm{PGF}_{2 \alpha}$ treatment was only significant $(P<0.05)$ in the group of cows treated $24 \mathrm{~h}$ before surgery.

Immunohistochemistry-tissue morphology. There were no significant differences in the numbers of $\mathrm{T}$ lymphocytes $\left(\mathrm{CD}^{+}, \mathrm{CD}^{+}, \mathrm{CD} 4^{+}\right)$or macrophages in control or treated animals (Table 5). However, the numbers of MHC class II molecules (DQ and DR) were significantly higher $(P<0.05) 6,12$ and $24 \mathrm{~h}$ after $\mathrm{PGF}_{2 \alpha}$ treatment compared with controls (Fig. 3). B lymphocytes were present in very low numbers as in Expts 1 and 2. Eosinophil populations in $\mathrm{PGF}_{2 \alpha}$-treated animals were variable, with some animals having up to 21 positive cells per field (Table 5). Although the data did not reach statistical significance, apart from stage I corpora lutea, only the corpora lutea from $\mathrm{PGF}_{2 \alpha}$-treated animals had more than one or two eosinophils per field.

The decrease in circulating progesterone concentrations indicated that functional luteolysis was taking place, although the corpus luteum was non-functional (progesterone $<1 \mathrm{ng}$ $\mathrm{ml}^{-1}$ ) only in the group treated $24 \mathrm{~h}$ after $\mathrm{PGF}_{2 \pi}$ injection. However, examination of sections stained with haematoxylin and eosin showed evidence of advanced structural luteolysis in all $\mathrm{PGF}_{2 \alpha}$-treated animals. The alteration in luteal structure was rapid, with very little difference among corpora lutea removed 6,12 or $24 \mathrm{~h}$ after $\mathrm{PGF}_{2 \alpha}$ treatment. All sections showed loss of luteal cell structure, few distinct large luteal cells and a very fibrous appearance in comparison with corpora lutea from control animals (Fig. 4a,b).

\section{Reverse transcription-polymerase chain reaction}

Validation of reverse transcription-polymerase chain reaction. Digestion with restriction enzymes resulted in specific 
Table 5. Immune cell populations (mean \pm SEM) in corpora lutea collected $0,6,12$ and $24 \mathrm{~h}$ after prostaglandin $\mathrm{F}_{2 \alpha}$ treatment

\begin{tabular}{|c|c|c|c|c|}
\hline & \multicolumn{4}{|c|}{ Time after prostaglandin $\mathrm{F}_{2 \alpha}$ treatment } \\
\hline & $0 \mathrm{~h}$ (control) & $6 \mathrm{~h}$ & $12 \mathrm{~h}$ & $24 \mathrm{~h}$ \\
\hline CD5' & $27.92 \pm 3.20$ & $30.67 \pm 8.60$ & $21.67 \pm 3.90$ & $51.38 \pm 17.30$ \\
\hline CD8 & $12.11 \pm 4.20$ & $11.08 \pm 3.30$ & $8.17 \pm 2.20$ & $11.96 \pm 1.90$ \\
\hline $\mathrm{CD}^{+}{ }^{+}$ & $7.38 \pm 0.90$ & $5.16 \pm 0.50$ & $1.71 \pm 0.60$ & $13.67 \pm 6.50$ \\
\hline B cells & $0.04 \pm 0.05$ & 0 & $0.04 \pm 0.05$ & $0.04 \pm 0.05$ \\
\hline Macrophages & $9.21 \pm 2.60$ & $24.25 \pm 4.90$ & $11.5 \pm 2.20$ & $24.21 \pm 7.90$ \\
\hline Eosinophils & $0.38 \pm 0.10$ & $3.75 \pm 1.40$ & $1.0 \pm 0.30$ & $5.63 \pm 3.50$ \\
\hline
\end{tabular}

Each figure represents the mean \pm SEM results from four corpora lutea.

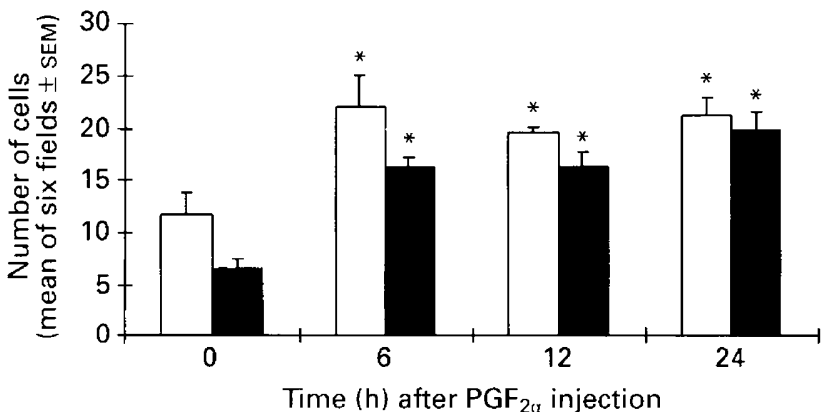

Fig. 3. MHC II expression (DQ and DR) in bovine luteal tissue 6, 12 and $24 \mathrm{~h}$ after $\mathrm{PGF}_{20}$-induced luteolysis on day 10 of the oestrous cycle. $\square$, TH14B; $\square$, VPM36. *Significantly different $(P<0.05)$.

products of the expected size for both cytokines. In addition, the size of the PCR products corresponded to the products of PCR of the individual cytokine plasmids.

Polymerase chain reaction results from luteal tissue. Only luteal tissue from Expts 2 and 3 was studied. PCR products corresponding to the expected sizes for both cytokines were found in all samples (Fig. 5). There was some variation in the intensity of the bands produced among animals but not among groups. The consistent intensity of the PCR product for ATPase confirmed that any variation among separate samples was not caused by uneven loading of CDNA.

\section{Discussion}

Immunohistochemistry was used to locate and quantify immune cells and MHC class II molecules in bovine corpora lutea recovered at different stages of the oestrous cycle, around the time of natural luteolysis and after induced luteolysis. It was shown that immune cell populations and the numbers of MHC class II molecules are not static, but vary during the lifespan of the bovine corpus luteum. This is the first study to look in detail at the immune cell populations specifically around the time of natural luteolysis. RT-PCR was then used to examine the expression of mRNA encoding TNF- $\alpha$ and IFN- $\gamma$ in corpora lutea. Messenger RNA for both cytokines was detected in all luteal tissue studied.
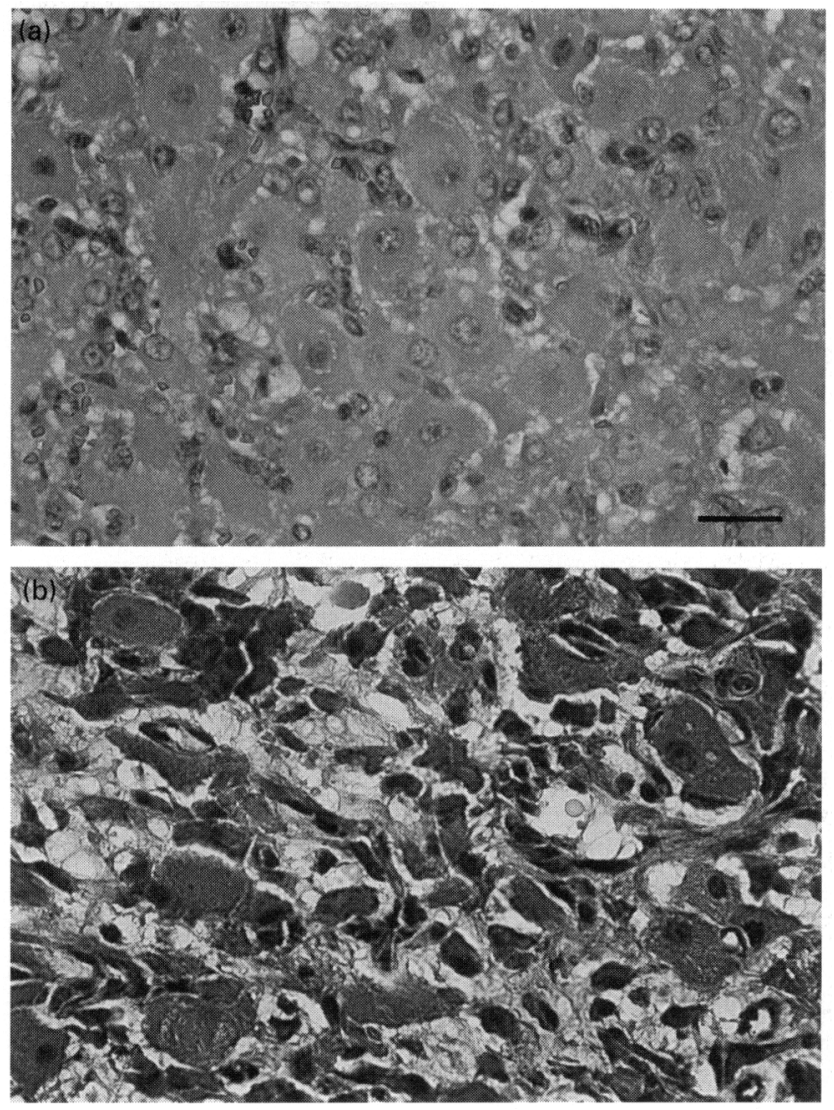

Fig. 4. The appearance of bovine luteal tissue (a) on day 10 of the oestrous cycle (control animal), and (b) $12 \mathrm{~h}$ after $\mathrm{PGF}_{2 x}$-induced luteolysis on day 10 of the oestrous cycle. Scale bar represents $30 \mu \mathrm{m}$.

The most important finding of this study was the significant increase in the number of $\mathrm{T}$ lymphocytes $\left(\mathrm{CD}^{+} / \mathrm{CD}^{+}\right)$within the cow corpus luteum before functional luteolysis, which provided evidence of a role for the immune system before its involvement in structural regression. The stimulus for this apparent influx of $T$ cells is not known, although increasing $\mathrm{PGF}_{2 \alpha}$ concentrations from around day 14 onwards could be involved (Kindahl et al., 1976; Parkinson and Lamming, 1990). The specific role of these T lymphocytes within luteal tissue around the time of luteolysis is also unclear. $\mathrm{PGF}_{2 \alpha}$ from the uterus has been 
(a)

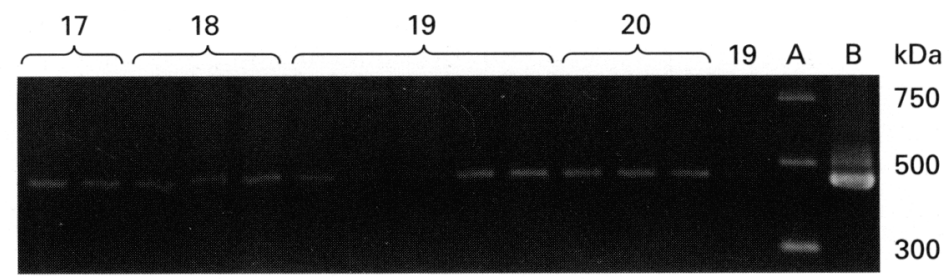

(b)

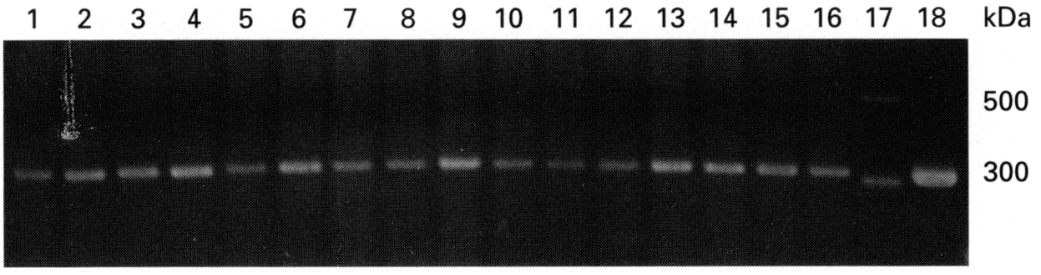

Fig. 5. (a) Reverse transcriptase polymerase chain reaction (RT-PCR) of mRNA encoding tumour necrosis factor $\alpha$ (TNF- $\alpha$ ) from bovine corpora lutea collected around the time of natural luteolysis (days 16-20). The PCR products were separated by gel electrophoresis and stained with ethidium bromide. The age of the corpus luteum is shown above each lane. Corpora lutea in lanes 1-9 were still functional (progesterone $>1 \mathrm{ng} \mathrm{ml}^{-1}$ ) and corpora lutea in lanes 10-14 had undergone functional luteolysis (progesterone $<1 \mathrm{ng} \mathrm{ml}^{-1}$ ). Lane 15 is a molecular weight marker and lane 16 is the positive control bovine TNF- $\alpha$ plasmid. (b) RT-PCR of mRNA encoding interferon $\gamma($ IFN- $\gamma$ ) from bovine corpora lutea collected $0,6,12$ and $24 \mathrm{~h}$ after treatment with $25 \mathrm{mg} \mathrm{PGF}_{2 x^{\prime}}$. Lanes 1-4: control cows (day 10 of the oestrous cycle); lanes 5-8: $6 \mathrm{~h}$ after treatment with $\mathrm{PGF}_{2 \alpha} ;$ lanes 9-12: $12 \mathrm{~h}$ after treatment with $\mathrm{PGF}_{2 \alpha}$; lanes 13-16: $24 \mathrm{~h}$ after treatment with $\mathrm{PGF}_{20}$; lane 17: molecular weight marker; and lane 18: the positive control, IFN- $\gamma$ plasmid.

shown to be the primary luteolytic substance in cows (Auletta and Flint, 1988). However, the cellular processes around the time of luteolysis are less clearly defined.

Lymphocytes are known to produce a range of cytokines, including TNF- $\alpha$ and IFN- $\gamma$, which, along with IL-1 $\beta$, have been shown to affect luteal cell function in vitro (Pate, 1995). The overall effect of these cytokines, alone or in combination, is primarily luteolytic, that is, to reduce progesterone production and increase production of a variety of prostaglandins, including $\mathrm{PGF}_{2 \alpha}$. Therefore, it is possible that $T$ lymphocytes exert their effects locally through cytokine production within the corpus luteum. No evidence was found of a variation in mRNA expression for either of the cytokines investigated in this study. Messenger RNA encoding TNF- $\alpha$ and IFN- $\gamma$ was present in all corpora lutea studied. However, further studies, to identify the specific cell sources of these substances and to identify and quantify cytokine protein, are required to investigate more fully cytokine production within the corpus luteum.

Lobel and Levey (1968) first observed lymphocytes and macrophages in the bovine corpus luteum, describing their presence as significant from day 14 onwards, associated with involution of luteal tissue. Since then, studies of the cellular composition of the bovine corpus luteum have focused primarily on luteal cell populations, with immune cells usually classified as 'non-luteal cells' and not quantified (O'Shea et al., 1989; Lei et al., 1991; Parkinson et al., 1994). Immunohistochemical techniques have been used to identify and quantify immune cell populations in corpora lutea from a variety of species including rabbits (Bagavandoss et al. 1988), pigs (Standaert et al., 1991) and humans (Brannstrom et al., 1994). There is a distinct variation in cell populations present within corpora lutea from different species. An immunohistochemical study in the bovine ovary, using visually staged corpora lutea, described populations of immune cells within the corpus luteum (Spanel-Borowski et al., 1997). A significant increase in the total number of leukocytes was observed between the development and regression stages of the corpus luteum. However, in contrast to our results, Spanel-Borowski et al. (1997) failed to detect any $\mathrm{CD}^{+}$or $\mathrm{CD}^{+} \mathrm{T}$ lymphocytes within luteal tissue. The reason for this is unclear but could reflect the different tissue preparation and immunohistochemical techniques used in the two studies.

Visually staged tissue was used to demonstrate that the numbers of macrophages, $\mathrm{T}$ lymphocytes (in particular $\mathrm{CD}^{+}$ cytotoxic-suppressor T cells) and MHC II expression were significantly higher at stage IV (day 19-21) of the oestrous cycle than at other stages. These findings are in agreement with flow cytometric studies by Fairchild Benyo et al. (1991), in which an increase in MHC class II molecules as the corpus luteum aged and after induced luteolysis was described. Corpora lutea at this stage are undergoing structural luteolysis and so the presence of immune cells and an increase in the numbers of MHC class II molecules supports the role of the immune system in the rapid dissolution of luteal tissue. The involvement of these cells in luteal cell destruction and phagocytosis has been taken to be their 
primary role within the corpus luteum for some time (Paavola, 1979; Bagavandoss et al., 1988).

The immunohistochemistry results and histological changes seen in stage IV corpora lutea were different from those seen in corpora lutea collected from cows on a known day of the cycle, after natural luteolysis. Using histological examination of sections stained with haematoxylin and eosin, it was only possible to identify signs of structural luteolysis (luteal cell shrinkage, loss of structure) in one of the five cows that underwent natural luteolysis in Expt 2. However, all stage IV corpora lutea from Expt 1 showed clear signs of structural luteolysis. In addition, the gross appearance of corpora lutea from all five cows around natural luteolysis corresponded to corpora lutea categorized as stage III using the technique described in Expt 1 (Ireland $e t$ al., 1980). It is concluded that the variation in results after natural luteolysis compared with stage IV is due to visually staged tissue being at a more advanced stage of luteolysis. Similarly, there was no increase in T-lymphocyte numbers in stage III corpora lutea (day 13-18) collected from the abattoir, although a significant increase was observed in corpora lutea from day 16 onwards in accurately dated corpora lutea. This result may have been due to chance selection of early stage III (day 13-15) corpora lutea. Both these observations reflect the problems associated with visual assessment of corpora lutea collected from animals with no reproductive history.

During the course of this study, corpora lutea collected after induced luteolysis were shown to be significantly different from those collected after natural luteolysis. MHC class II molecules within luteal tissue were increased significantly at all periods after $\mathrm{PGF}_{2 \alpha}$ treatment. However, there was no change in the populations of $\mathrm{T}$ lymphocytes or macrophages, as had been observed in both visually staged corpora lutea during the oestrous cycle and corpora lutea collected around natural luteolysis. Morphologically, there was a rapid loss of distinct cell structure and luteal tissue bore little resemblance to stage IV (day 19-21) corpora lutea or corpora lutea after natural luteolysis. $\mathrm{PGF}_{2 \alpha}$-induced structural luteolysis appeared to proceed much more rapidly than it does in the normal oestrous cycle and the types of cell changes observed, particularly immune cell changes, were quite different. It appears that induced luteolysis using single bolus injections of high concentrations of $\mathrm{PGF}_{2 \alpha}$ is of only limited value as a model for studying cellular events around luteolysis. Physiological concentrations of $\mathrm{PGF}_{2 \alpha^{\prime}}$ infused gradually, in a pulsatile manner may be a more useful model.

In the present study, eosinophils were present in large numbers at stage I (days 1-5) of the oestrous cycle. Eosinophils have been described in some detail in the sheep ovary, in which they are seen in large numbers in the follicle at ovulation (Cavender and Murdoch, 1988) and after PGF ${ }_{2 \alpha}-$ induced luteolysis (Murdoch, 1987). However, a significant increase in the number of eosinophils after $\mathrm{PGF}_{2 \alpha}$-induced luteolysis in cows was not found.

This apparent eosinophilia during early corpus luteum formation in cows has not been described in other species. It is difficult to suggest a role for these cells at this time. However, large numbers of mast cells have been recorded in the pre-ovulatory follicles of cows, but mast cells are not present in such numbers in the early corpus luteum
(Nakamura et al., 1987). The decrease in mast cell numbers at this time may be due to degranulation of these cells induced as a consequence of the LH surge before ovulation, a process that has been described in hamsters by Krishna and Terranova (1985). Substances released from degranulating mast cells act as specific chemoattractants for eosinophils, which may explain the presence of large numbers of eosinophils in the early corpus luteum.

In conclusion, immune cell populations and MHC class II molecules have been shown to vary during the lifespan of the cow corpus luteum. In particular, a significant increase in $\mathrm{T}$ lymphocytes was seen in corpora lutea before functional luteolysis. Therefore, these cells, with their great capacity to affect surrounding cells, may be involved in events occurring in luteal tissue around the time of natural luteolysis, although the exact nature of their role is not clear. This study provides further evidence that the immune system plays a significant role around the time of luteolysis in cows.

L. A. Penny is in receipt of a Wellcome Veterinary Research Training Scholarship. The authors wish to thank P. Dixon and $\mathrm{H}$. Tremayne for assistance with animal work, the Department of Veterinary Pathology for technical help and C. Hogg for assistance with molecular biology.

\section{References}

Adashi EY (1992) The potential relevance of cytokines to ovarian physiology Journal of Steroid Biochemistry and Molecular Biology $43439-444$

Alila HW and Hansel W (1984) Origin of different cell types in the bovine corpus luteum as characterized by specific monoclonal antibodies Biology of Reproduction 31 1015-1025

Armstrong DG and Hogg CO (1992) The expression of a putative growth factor 1 receptor gene in the liver of the developing chick Journal of Molecular Endocrinology 8 193-201

Auletta FJ and Flint APF (1988) Mechanisms controlling corpus luteum function in sheep, cows, nonhuman primates and women, especially in relation to the time of luteolysis Endocrine Reviews 9 88-105

Bagavandoss P, Kunkel SL, Wiggins RC and Keyes PL (1988) Tumor necrosis factor- $\alpha$ (TNF- $\alpha$ ) production and localisation of macrophages and $T$ lymphocytes in the rabbit corpus luteum Endocrinology 122 1185-1187

Best CL, Pudney J, Welch WE, Burger N and Hill JA (1996) Localisation and characterisation of white blood cell populations within the human ovary throughout the menstrual cycle and menopause Human Reproduction 11(4) 790-797

Brannstrom M, Pascoe V, Norman RJ and McClure N (1994) Localization of leukocyte subsets in the follicle wall and in the corpus luteum throughout the human menstrual cycle Fertility and Sterility 61 488-495

Cavender JL and Murdoch WJ (1988) Morphological studies of the microcirculatory system of periovulatory ovine follicles Biology of Reproduction 39989-997

Chomczynski P and Sacchi N (1987) A single step method of RNA isolation by acid guanidium thiocyanate-phenol-chloroform extraction Analytical Biochemistry 161 156-159

Corrie JET, Hunter WM and Macpherson JS (1981) A strategy for radioimmunoassay of plasma progesterone with the use of a homologous site ${ }^{125}$-labelled radioligand Clinical Chemistry 27 594-599

Dutia BM, MacCarthy-Morrogh L, Glass EJ, Knowles G, Spooner RL and Hopkins J (1995) Discrimination between major histocompatibility complex class II DQ and DR locus products in cattle Animal Genetics 26 111-114

Fairchild Benyo DL, Haibel GK, Laufman HB and Pate JL (1991) Expression of major histocompatability complex antigens on the bovine corpus luteum during the estrous cycle, luteolysis and early pregnancy Biology of Reproduction 45 229-234.

Hsu SM, Raine L and Fanger $\mathbf{H}$ (1981) The use of the avidin-biotinperoxidase complex $(\mathrm{ABC})$ immunoperoxidase technique. A comparison 
between $\mathrm{ABC}$ and unlabelled antibody (PAP) procedures Journal of Histochemistry and Cytochemistry 29 577-580

Howard CJ and Morrison H (1991) Leukocyte antigens in cattle, sheep and goats Veterinary Immunology and Immunopathology 27 1-36

Howard CJ, Parsons KR, Jones BV, Sopp P and Pocock DH (1988) Two monoclonal antibodies (CC17, CC29) recognising an antigen (Bo5) on bovine T lymphocytes, analogous to human CD5 Veterinary Immunology and Immunopathology 19 127-139

Hunt JS (1993) Expression and regulation of the tumor necrosis factor- $\alpha$ gene in the female reproductive tract Reproduction, Fertility and Development 5 $141-53$

Ireland JJ, Murphee RL and Coulson PB (1980) Accuracy of predicting stages of bovine estrous cycle by gross appearance of the corpus luteum Journal of Dairy Science 63 155-160

Ji I, Slaughter RG, Ellis JA, Ji TH and Murdoch WJ (1991) Analyses of ovine corpora lutea for tumor necrosis factor $\mathrm{mRNA}$ and bioactivity during prostaglandin-induced luteolysis Molecular and Cellular Endocrinology 81 $77-80$

Kindahl H, Edqvist LE, Bane A and Granstrom E (1976) Blood levels of progesterone and 15-keto- 13,14-dihydro-prostaglandin $F_{2 x}$ during the normal oestrous cycle and early pregnancy in heifers Acta Endocrinologica 82 134-149

Krishna A and Terranova PF (1987) Alterations in mast cell degranulation and ovarian histamine in the pro-oestrous hamster Biology of Reproduction 32 $1211-1217$

Law AS, Baxter G, Logue DN, O'Shea T and Webb R (1992) Evidence for the action of bovine follicular fluid factor(s) other than inhibin in suppressing follicular development and delaying oestrus in heifers journal of Reproduction and Fertility 96 603-616

Lawler DF, Broadley C and Watson ED (1994) Immunohistochemical localisation of lymphocyte populations in the equine corpus luteum fournal of Reproduction and Fertility Abstract Series 1383

Lei ZM, Chegini N and Rao CV (1991) Quantitative cell composition of human and bovine corpora lutea from various reproductive states Biology of Reproduction 44 1148-1156

Lendrum AC (1944) The staining of eosinophil polymorphs and enterochromaffin cells in histological sections Journal of Pathology and Bacteriology 56441

Lobel BL and Levy E (1968) Formation, development and involution of corpora lutea Acta Endocrinologica 132 35-51

Mori T (1990) Immuno-endocrinology of cyclic ovarian function American Iournal of Reproductive Immunology 23 80-89

Murdoch WJ (1987) Treatment of sheep with prostaglandin $F_{2 \alpha}$ enhances production of a luteal chemoattractant for eosinophils American journal of Reproductive Immunology and Microbiology 15 52-56

Nakamura Y, Smith M, Krishna A and Terranova PF (1987) Increased number of mast cells in the dominant follicle of the cow: relationships among luteal, stromal and hilar regions Biology of Reproduction 37 546-549

Niswender GD, Reimers TJ, Diekman MA and Nett TM (1976) Blood flow: a mediator of ovarian function Biology of Reproduction 14 64-81

Niswender GD, Schwall RH, Fitz TA, Farin CE and Sawyer H (1985) Regulation of luteal function in domestic ruminants: new concepts Recent Progress in Hormone Research 41 101-143

O'Shea JD, Rodgers RJ and D'Occhio MJ (1989) Cellular composition of the cyclic corpus luteum of the cow Journal of Reproduction and Fertility 85 483-487

Paavola LG (1979) The corpus luteum of the guinea pig IV. Fine structure of macrophages during pregnancy and postpartum luteolysis and the phagocytosis of luteal cells American Journal of Anatomy 154 337-364.

Parkinson TJ and Lamming GE (1990) Interrelationships between progesterone, 13,14-dihydro-15-keto PGF-2 $\alpha$ (PGFM) and LH in cyclic and early pregnant cows Journal of Reproduction and Fertility 90 221-233

Parkinson TJ, Turvey A and Jenner LJ (1994) A morphometric analysis of the corpus luteum of the cow during the estrous cycle and early pregnancy Theriogenology 41 1115-1126

Pate JL (1995) Involvement of immune cells in regulation of ovarian function Journal of Reproduction and Fertility Supplement 49 365-377

Roby KF and Terranova PF (1989) Localization of tumor necrosis factor (TNF) in the rat and bovine ovary using immunocytochemistry and cell blot: evidence for granulosa production. In Growth factors and the Ovary pp 273-278 Ed. AN Hirshfield. Plenum Press, New York

Roitt IM (1991) The acquired immune response. In Essential Immunology 7th edn pp 129-151 Blackwell Scientific Publications, Oxford

Shaw DW and Britt JH (1995) Concentrations of tumor necrosis factor $\alpha$ and progesterone within the bovine corpus luteum sampled by continuous-flow microdialysis during luteolysis in vivo. Biology of Reproduction 53 847-854

Spanel-Borowski K, Rahner P and Ricken AM (1997) Immunolocalisation of CD18-positive cells in the bovine ovary Journal of Reproduction and Fertility 111 197-205

Standaert FE, Zamora CS and Chew BP (1991) Quantitative and qualitative changes in blood leukocytes in the porcine ovary American Journal of Reproductive Immunology 25 163-168

Terranova PF, Sancho-Tello M and Hunter VJ (1993) Tumor necrosis factor- $\alpha$ and ovarian function. In The Ovary pp 395-411 Eds E Adashi and PCK Leung. Raven Press, New York

Vinatier D, Dufour P, Tordjeman-Rizzi N, Prolongeau JF, Depret-Moser S and Monnier JC (1995) Immunological aspects of ovarian function: role of the cytokines European Journal of Obstetrics and Gynecology and Reproductive Biology 63 (2) 155-168

Wang LJ, Pascoe V, Petrucco OM and Norman RJ (1992) Distribution of leukocyte subpopulations in the human corpus luteum Human Reproduction 7 197-202 